DOI: $10.20472 /$ IAC.2019.045.034

\author{
INESE PELŠA \\ University of Latvia, Latvia \\ NORA KIIBILDA - KINNA \\ University of Latvia, Latvia \\ JANA SIMANOVSKA \\ Vidzeme University of Applied Sciences, Latvia
}

\title{
APPLYING GREEN PUBLIC PROCUREMENT TO FOOD SUPPLY AND CATERING SERVICES:CASE STUDY IN LATVIA
}

\begin{abstract}
:
Green public procurement (GPP) is a process whereby public and municipal authorities seek to procure goods and services with the lowest environmental impact throughout their entire life cycle, taking into account also the life cycle costs compared to products with the same primary function. GPP can reduce not only the environmental impact, but also promote social benefits and budget savings. The requirements for GPP and the procedure for its application in Latvia are determined by governmental regulations. That requires mandatory application of the GPP to seven groups of goods and services, among them food and catering services.
\end{abstract}

In 2017, the share of total procurements that self reported application of GPP was $11.8 \%$ in financial expression, but in 2018 - 18.4\%. In 2017, according to self reports $54 \%$ of all food product tenders and $79 \%$ catering services were marked as GPP tenders. In 2018 already $90 \%$ of all food product tenders and $99 \%$ catering services are marked as GPP tenders. However, to what extent we can rely on self reports?

To evaluate application of GPP requirements for food products and catering services, we screened in total 106 tenders ( 73 tenders for the supply of food products and 33 for catering services), which were published from July 1, 2017 till July 1, 2018, comparing the tender documents with the governmental regulations. We found that the terms in the Technical Specifications and other tender documents were often unclear. The most common included criterion was requirement that the food products supplied may not contain or be produced from genetically modified organisms (97\%). While the second most frequently used criterion is so called higher quality food (28\%) e.g. certified as organic, national quality schemes or from integrated agriculture. However, only $4 \%$ of the tender documents gave higher priority exclusively for organic food compared to local quality schemes or integrated agriculture. Considering that organic foods are usually higher priced, it can be assumed that only in $4 \%$ of cases procurements result in delivering organic food. $18 \%$ of the tenders require foods from the national food quality scheme, and $16 \%$ of the tenders require products from either organic farming or integrated agriculture. In order to promote organic food, purchasers should more clearly require organic products.

\section{Keywords:}

Green public procurement, food and catering services, case study Latvia 
JEL Classification: H70, Q50 